\title{
PERKECUALIAN TERHADAP PRINSIP LARANGAN PEMBATASAN KUOTA IMPOR TERKAIT PENANAMAN MODAL DI INDONESIA
}

\author{
Resa Raytiaputri \\ Fakultas Hukum Universitas Merdeka Malang \\ Jl. Terusan Raya Dieng Nomor 62-64 Malang \\ E-mail: resa.raytia@unmer.ac.id
}

\begin{abstract}
The existence of an exception from the principle of prohibition on quantitative restrictions related toinvestments is still not fully reflect justice, especially for developing countries like Indonesia, there is still available a reproach for developed countries or there is multinational companies that havethe advantage of capital to take precedence over their interests, but all back at a venture and the power of a country especially developing countries to be able to maintain the sovereigntyof his own country from excessive imports. Awareness of the defeat by developing countries regarding technology and capabilities of the product markets of developed countries, made the consistency policies be importance and rules oflegislation as oneof protection for Indonesia's national interests amid global competition especially in the fieldof international trade in capital investment. Considering the capital investment is also needed by Indonesia as one of the efforts to build the national economyand it is very related to international trade.
\end{abstract}

Key Words: Fairness, Exception, Quota, Trade, Investment.

\begin{abstract}
ABSTRAK
Keberadaan aturan perkecualian dari prinsip larangan pembatasan kuota impor terkait penanaman modal dirasa masih belum sepenuhnya mencerminkan keadilan khususnya bagi negara berkembang seperti Indonesia, masih ada cela bagi negara maju atau perusahaan multinasional yang memiliki keunggulan modal untuk diutamakan kepentingannya, namun semua kembali pada usaha maupun kekuatan suatu negara terutama negara berkembang untuk dapat mempertahankan kedaulatan negaranya sendiri dari impor yang berlebihan. Kesadaran dari kalahnya negara berkembang mengenai teknologi maupun kemampuan pasar produk dari negara maju, menjadikan pentingnya konsistensi kebijakan maupun aturan perundang-undangan sebagai salah satu proteksi bagi kepentingan nasional Indonesia ditengah persaingan global khususnya di bidang perdagangan internasional dalam penanaman modal. Mengingat penanaman modal juga dibutuhkan oleh Indonesia sebagai salah satu upaya membangun perekonomian negara dan erat kaitannya dengan perdagangan internasional.
\end{abstract}

Kata Kunci: Dagang, Keadilan, Modal, Kuota, Perkecualian.

Perekonomian dan perkembangan yang terus menerus mengalami modernisasi, mengakibatkan ekonomi suatu negara dengan negara lain semakin erat hubungannya serta saling mempengaruhi. Bentuk dari hubungan-hubungan tersebut seperti transaksi ekonomi berupa perdagangan barang 
ataupun jasa dan transaksi investasi penanaman modal serta transaksi finansial utang piutang. Perkembangan yang dialami oleh perekonomian berjalan secara selaras bersama dengan kebutuhan manusia yang turut mengalami perubahan, perkembangan dan muncul beragam variasi terkait dengan macam, jenis, kualitas, kuantitas maupun bentuknya. Sedangkan sarana, prasarana ataupun fasilitas untuk memenuhi tuntutan kebutuhan manusia tersebut masih terbilang kurang dan terbatas, baik itu kebutuhan berupa barang ataupun jasa.

Memenuhi kebutuhan tersebut, maka dilakukan hubungan perekonomian yang melibatkan para pihak yang berkaitan dalam menuntut kebutuhan maupun kepentingannya tersebut, hal ini juga dapat dikatakan sebagai penyelesaian, yang biasanya disebut dengan perdagangan. Kegiatan dimana terdapat transaksi berupa jual beli suatu barang ataupun jasa dengan tujuan untuk mengalihkan hak atas barang maupun jasa yang dilaksanakan terus menerus dengan disertai adanya imbalan ataupun kompensasi seperti yang tercantum di dalam Surat Keputusan Menteri Perindustrian dan Perdagangan Nomor 23/MPP/ Kep/1/1998 mengenai Pelaksanaan Dari LembagaLembaga Usaha Perdagangan.

Perdagangan memiliki ruang lingkup yaitu perdagangan luar negeri dan perdagangan dalam negeri. Perdagangan dalam negeri merupakan suatu kegiatan yang mencakup transaksi jual beli barang dan atau jasa yang dilakukan terus menerus di wilayah suatu negara, di samping itu yang diartikan dengan perdagangan luar negeri yaitu suatu perdagangan atau kegiatan meliputi transaksi jual beli yang dilakukan oleh penduduk suatu negara dengan penduduk negara yang lain sebagai rekan dari suatu transaksi atas dasar landasan kesepakatan yang dibuat secara bersama oleh para pihak terkait. Pihak terkait dalam transaksi yang dimaksud dapat berupa antar perorangan atau individu dengan individu, antara individu dengan pemerintah pada suatu negara atau pemerintah di suatu negara dengan pemerintah pada negara lain.

Perputaran barang yang diperjual belikan di suatu negara atau antara negara tidak lepas dari proses produksi yang membutuhkan modal, bahan dasar, alat produksi, tempat maupun teknologi yang digunakan dalam proses pengolahannya. Faktor-faktor itulah yang secara garis besar memicu munculnya kegiatan penanaman modal, baik penanaman modal dalam negeri maupun penanaman modal yang melintasi batas negara sehingga biasa disebut sebagai penanaman modal asing. Sehingga penanaman modal dan perdagangan menjadi satu kesatuan yang hampir tidak dapat dipisahkan. Hukum perdagangan internasioal dan hukum penanaman modal pada dasarnya saling mempengaruhi (Hendrik Budi Untung, 2013, 113).

Tujuan dari hukum perdagangan internasional adalah untuk menghilangkan hambatanhambatan yang dapat menjadi penghalang dibukanya pasar internasional secara luas. Pasar internasional yang terbuka akan menunjang perubahan pola bisnis dari perusahaan multinasional dengan cara dilakukannya investasi ke lain negara dengan tujuan pemenuhan permintaan dari pasar internasional dan mendekatkan diri kepada para pihak konsumen dari pasar.

United Nations Conference on Trade and Employment di Havana dimulai dan dilaksanakan sejak tahun 1948 sebagai upaya untuk mewujudkan suatu penataan dalam bidang investasi asing dengan cara multilateral. Melalui konferensi ini pula dibentuk Havana Charter yang berisikan bahwa adanya permintaan kepada seluruh negara-negara yang menjadi peserta untuk mengambil sikap dan menjauh dari perlakuan yang bersikap diskriminatif terhadap penanam modal dari asing (New York, 1991, 79). Namun para pihak-pihak yang berposisi sebagai penandatangan dari persetujuan ratifikasi Havana Charter telah melakukan penolakan. Maka mulai dari sejak saat itu negara-negara peserta menjadi kurang membicarakan dan memper- 
hatikan kebijakan investasi dan perdagangan, yang pada akhirnya mereka hanya lebih memfokuskan pada persoalan di bidang liberalisasi perdagangan (Mari Pangestu, 1996, 34).

Kondisi tersebut seiring bertambah waktu telah mengalami perubahan yang berangsur setelah dilaksanakannya Uruguay Round pada kurun waktu tahun 1986-1994, yang di dalam pembahasannya menitik beratkan pada permasalahan penting mengenai penanaman modal yang terkait di dalam pembicaraan tentang perdagangan internasional. Maka pada saat itu lah muncul General Agreement on Tariff and Trade (GATT) yang memiliki harapan dapat mengantisipasi dan menyelesaikan segala persoalan dan praktik-praktik perdagangan yang dapat menghambat pembentukan dan pembangunan pasar bebas dikarenakan dampak dari perang dunia dan perang dingin yang telah terjadi di antara blok barat dan blok timur.

Namun demikian, karena kehidupan masyarakat dunia yang terus semakin dinamis, maka dengan semakin beragam serta bersifat kompleksnya hubungan, tuntutan serta transaksi ekonomi secara internasional sehingga mengakibatkan aturan-aturan hukum ekonomi internasional menjadi sama beragam serta kompleks (N. Rosyidah Rakhmawati, 2006, 42-43). Salah satu pokok perhatian yang dijadikan bahan analisa oleh penulis di dalam tulisan ini yaitu mengenai peranan dari penanaman modal bagi keberlangsungan perdangan internasional yang membawa kegunaan maupun manfaat bagi masing-masing negara pelaksananya. Penanaman modal itu sendiri menjadi sorotan dan dibahas dalam Trade Related Investment Measures (TRIMs).

Kebutuhan yang dimiliki negara berkembang dengan tujuan untuk memajukan pembangunan nasional di negerinya disadari perlu mendapat penunjang dari pelaksaannya berupa modal atau kerja sama dari pihak asing. Maka banyak negara maju yang menanamkan modal pada negara berkembang. Penyebab yang menjadi faktor dominan mengapa terjadinya penanaman modal di negara berkembang oleh negara maju ialah dikarenakan negara maju memiliki keunggulan komparatif yang lebih baik dalam hal menghasilkan produk daripada negara berkembang dan pelaksanaan proses produksi yang telah diterapkan di negaranya sudah lebih mengalami kemajuan, maka sudah pasti negara maju memiliki kecenderungan berposisi sebagai penanam modal (investor), di samping itu negara berkembang lah yang menduduki posisi sebagai negara penerima modal/host country (N. Rosyidah Rakhmawati, 2004, 13).

Investasi sebenarnya memiliki tujuan utama yang mendasar dalam pelaksanaannya yaitu ingin memberikan keuntungan bagi tiap negara yang berikatan di dalam perjanjian pelaksanaan investasi itu sendiri, mengingat keberadaan investasi di dalam suatu negara membawa dampak ataupun manfaat yang beragam dan luas (multiplier effect). Bila lebih dikritisi dan dilakukan analisa lebih jauh mengenai hubungan antara investor dan host country, terdapat ketidak seimbangan antara kepentingan dari kedua pihak yang tercermin dari kecenderungan negara yang berposisi sebagai investor untuk mengambil keuntungan (profit oriented) bagi negaranya sendiri yang tak jarang akhirnya tidak memperhatikan kepentingan dari negara berkembang yang menjadi host country, dimana tujuan negara berkembang sebagai penerima modal adalah untuk mendukung pengembangan negaranya, kenyataannya ada kemungkinan malah menerima kerugian.

Cerminan dari ketidak seimbangan itu juga terlihat dari kaitannya dengan ketentuan yang dibuat oleh GATT, yaitu dimana GATT memberlakukan prinsip-prinsip umum liberalisasi perdagangan yang salah satunya menerapkan suatu aturan untuk memberlakukan semua negara yang tercatat sebagai anggota dalam perdagangan internasional dengan cara yang sama rata atau tidak boleh dibedakan perlakuannya. Padahal jika dilihat dari segi pandangan kondisi tiap negara khu- 
susnya antara negara maju dan negara berkembang, pasti negara berkembang akan mengalami kesulitan dan banyak kendala dalam persaingan serta cenderung mengalami kekalahan dalam persaingan menghadapi negara maju yang sudah memiliki kemampuan memproduksi serta bernegosiasi yang selangkah lebih depan di banding negara berkembang, sehingga dalam pelaksanaanya akan lebih banyak menentang kepentingan nasional atau tujuan utama dari suatu negara terutama negara berkembang.

Permasalahan berikutnya adalah terkait jaringan usaha yang dimiliki oleh penanam modal cenderung bersifat kuat dan luas, pada umumnya jaringan tersebut diwujudkan dalam bentuk Multinational Corporation yang tergabung dengan perusahaan induk, jadi akan mendorong pengutamaan dari layanan bagi negara asal atau pemilik modal di negara asal serta memposisikan negara berkembang yang dilayani paling akhir bahkan tidak menerima pelayanan.

Salah satu prinsip GATT yang menjadi sorotan bagi penulis dalam tulisan ini adalah Prinsip Larangan Restriksi Kuantitatif yang menyatakan bahwa setiap negara anggota tidak boleh menerapkan pembatasan impor maupun ekspor melalui kuota atau lisensi, yang selengkapnya terdapat dalam Artikel XI GATT. Namun disamping itu, juga terdapat prinsip yang sangat kontras dengan Artikel XI GATT yaitu Prinsip Perkecualian atas Larangan Restriksi Kuantitatif yaitu kebijakan pengaman atau The Safeguards Clause yang diatur dalam Artikel XIX GATT. Prinsip perkecualian tersebut diberlakukan apabila perjanjian GATT menimbulkan permasalahan berupa kerugian akibat lonjakan impor atau menjadi saingan hasil industri dalam negeri, yang banyak dialami oleh negara berkembang.

Salah satu contoh kasus yang dapat menjadi cerminan dari prinsip tersebut adalah seperti yang dialami oleh Indonesia di awal tahun 2013, yaitu Pemerintah Amerika Serikat yang secara menda- dak memutuskan membuat langkah pemberitahuan dan keberatan atas pembatasan impor produk hortikultura yang dilakukan oleh Indonesia kepada WTO (Bustanul Arifin, 2013). Langkah pemberitahuan yang dilakukan AS juga mengandung sebuah keberatan dari mereka terkait pembatasan dan pengaturan impor hewan dan produk hewan. Aturan dan kebijakan yang telah diambil oleh Indonesia ini diperkirakan akan mengganggu dan menjadi hambatan bagi impor hewan atau produk hewan dari AS.

Indonesia sedang melakukan sebuah upaya dalam pembangunan serta pengembangan hortikultura lokal, paling tidak dapat menjadi tuan rumah bagi bangsanya sendiri mengingat potensi pasar yang dimiliki Indonesia sendiri terbilang besar. Pasca mendapat banyak tekanan dari berbagai pihak, pemerintah mulai mendorong dan memajukan buah, sayur maupun bunga eksotik lokal yang tentunya memiliki keunggulan yang dapat dibandingkan dan bernilai saing.

Nilai dari impor produk-produk hortikultura pada tahun 2007 ada pada angka 798 juta dollar AS, kemudian pada tahun 2011 angka tersebut naik 1,7 miliar dollar AS. Pada Januari-Juli 2012 nilai impor tersebut menembus nilai hingga 1 miliar dollar AS atau setara dengan Rp 10 triliun. Pada tahun 2012, lebih separuh bagian dari nilai impor hortikultura, yaitu 600 juta dollar AS, diperoleh dari impor buah. Hal yang memilukan adalah bahwa buah impor Indonesia bukan hanya buah yang bersifat subtropis, pir, anggur, kiwi, dan seperti apel merah, namun juga berupa buah tropis yang banyak bisa ditemui di Indonesia sendiri, contohnya nangka dan durian. Kemudian secara berkala, pihak pemerintah khususnya Kementerian Pertanian dan Kementerian Perdagangan menghasilkan beberapa ketentuan dan aturan impor terkait hortikultura yang bermaksud untuk memberikan bentuk perlindungan bagi kaum petani hortikultura domestik atau yang ada di dalam negeri. 
Kemudian menurut pada aturan secara teknis impor hortikultura dalam Peraturan Menteri Pertanian Nomor 60 Tahun 2012 tentang Rekomendasi Impor Produk Hortikultura dan Peraturan Menteri Perdagangan Nomor 60 Tahun 2012 tentang Ketentuan Impor Produk Hortikultura, mulai berlaku pada September 2012. Proses dalam merumuskan suatu kebijakan yang sifatnya aktif-dinamis tersebut pastinya melahirkan bermacam-macam komentar dalam negeri sendiri. Setelah melalui beragam analisis baik dari segi ekonomi maupun politik kepentingan serta pemberlakuan yang mengalami kemunduran, maka berhenti pada keputusan bahwa larangan impor berlaku pada 11 (sebelas) produk hortikultura bagi periode mulai pada Januari-Juni 2013.

Kementerian Pertanian tidak memperkenankan impor untuk 6 (enam) jenis buah-buahan, yaitu durian, nanas, melon, pisang, mangga, dan papaya. Di samping buah, juga ada 4 (empat) jenis sayuran yang tidak diperkenankan, yaitu kentang, kubis, wortel, dan cabai. Kemudian 3 (tiga) jenis bunga, yaitu krisan, anggrek, dan helicona. Yang menjadi alasan utama yaitu permintaan produk holtikultura yang diminta sebenarnya masih bisa dipenuhi oleh produk holtikultura lokal atau yang diproduksi dalam negeri. Sehingga dalam hal ini, sepertinya Indonesia akan mengajukan jawaban pembenar berupa perdagangan adil disebabkan hortikultura belum didaftarkan seperti jagung, beras, gula dan kedelai. Serta aturan terkait klausul proteksi pada produk khusus tersebut dapat dibenarkan WTO selama diperuntukkan pengentasan rakyat miskin, pembangunan pedesaan dan ketahanan pangan. Jenis, macam dan rentang waktu dari produk hortikultura tentu terlalu beragam untuk didaftarkan sebagai produk yang bersifat khusus.

Sebagai negara yang berdaulat secara hukum dan politik, Indonesia sejak awal berpedoman pada Pasal 33 UUD 1945. Sehingga secara keseluruhan adanya ketegasan bahwa perekonomian nasional diselenggarakan berdasar atas demokrasi dengan prinsip kebersamaan, efisiensi berkeadilan, berkelanjutan, dan menjaga keseimbangan kemajuan serta kesatuan ekonomi nasional. Demi melindungi kepentingan nasional terutama yang berkaitan dengan perlindungan hukum bagi industri dalam negeri dari kerugian besar maupun ancaman kerugian besar, maka setelah disetujuinya sebuah pembahasan mengenai The Final Agreement to Establish WTO, Indonesia meratifikasinya dalam UU Nomor 7 tahun 1994 tentang pelaksanaan safeguard.

Indonesia juga sebagai negara berkembang kini telah memiliki sebuah Undang-Undang Nomor 25 tahun 2007 yang mengatur tentang Penanaman Modal yang diundangkan pada 29 Maret 2007. Peraturan yang berasas kepastian hukum, keterbukaan, akuntabilitas, non diskriminasi, dan kebersamaan. Prinsip besar yang sering dikaitkan dalam penanaman modal adalah prinsip most favored nation dan national treatment, namun sifat dari prinsip-prinsip itu sendiri merupakan prinsip yang bertujuan untuk melindungi kepentingan pemodal asing agar terhindar dari diskriminasi dan hambatan dalam pasar dagang internasional. Dengan kata lain, bisa dikatakan kepentingan nasional terutama industri dalam negeri yang menjadi pesaing dari barang impor menjadi lebih lemah dan rawan mengalami kerugian. Namun sebagai antisipasi dari munculnya kerugian atau tersainginya produk dalam negeri, Indonesia sekiranya memiliki bentuk peraturan-peraturan yang dapat mewujudkan dari Prinsip Perkecualian khususnya tentang kebijakan pengaman.

Latar belakang tersebut mengantarkan pada penganalisaan apakah dengan adanya aturan perkecualian terhadap prinsip Larangan Restriksi Kuantitatif sudah mencerminkan keadilan dalam bidang penanaman modal bagi Indonesia sebagai negara berkembang. Kemudian dilanjutkan pada pembahasan kedua yaitu tentang bagaimana perwujudan pengaturan prinsip perkecualian terhadap Larangan Restriksi Kuantitatif dalam pengaturan penanaman modal di Indonesia. 


\section{Perkecualian terhadap Prinsip Larangan Pembatasan Kuota Impor Terkait Penanaman Modal di Indonesia}

Resa Raytiaputri

\section{Metode Elaborasi}

Metode yang digunakan ialah penelitian berjenis normatif, kemudian menggunakan pendekatan kasus serta perundang-undangan dalam penyusunan pembahasan guna mencapai hasil analisa berdasar dari rumusan masalah yang diangkat

Pendekatan kasus menjadi pilihan penulis dalam menyusun pembahasan karena pendekatan ini mengarahkan penulis dalam memahami alasan hukum atau dasar argumentasi dalam menganalisa permasalahan berdasar pada kasus yang pernah terjadi terkait dengan penanaman modal dan perdagangan internasional khususnya mengaitkan Indonesia. Kemudian pendekatan perundangundangan juga menjadi pilihan penulis dengan alasan penganalisaan permasalahan yang bertitik pada cerminan keadilan dalam aturan perkecualian larangan restriksi kuantitatif atau pembatasan kuota yang tertuang dalam bentuk hukum tertulis, sehingga diperlukan langkah berupa penelaahan peraturan perundang-undangan di Indonesia.

Bahan hukum yang digunakan dalam artikel ilmiah ini bersifat primer dan sekunder yang bersumber pada aturan hukum positif mulai dari UUD 1945 hingga peraturan perundang-undangan lainnya terutama aturan penanaman modal di Indonesia yang diketahui berdasar Undang-Undang Nomor 25 Tahun 2007 tentang Penanaman Modal. Kemudian berbagai aturan yang mengikuti akan dianalisa dalam pembahasan menggunakan salah satu teknik analisa yaitu Economic Analysis of Law (analisis ekonomi atas hukum), mengingat jurnal ini membahas bagaimana peran hukum dalam bidang ekonomi, kemudian sebaliknya perekonomian itu juga mempengaruhi hukum. Perdagangan internasional dan penanaman modal yang termasuk dalam bidang ekonomi yang keberlangsungannya tidak lepas dari hukum yang diterapkan.

\section{Keberadaan dari Aturan Perkecualian}

Mengingat Indonesia berposisi sebagai salah satu negara yang berkembang, sehingga penulis menganalisa untuk memperoleh kesimpulan apakah keadilan sudah tercermin dalam aturan tersebut. Sebelum menganalisa lebih dalam, maka perlu diketahui dulu tentang aturan perkecualian yang diberlakukan oleh WTO.

1. Aturan Perkecualian Terhadap Prinsip Larangan Restriksi Kuantitatif dalam GATT

Aturan-aturan perkecualian dalam hukum WTO dapat digolongkan ke dalam beberapa macam bentuk perkecualian, namun yang menjadi fokus bagi penulis adalah perkecualian ketika berada dalam keadaan ekonomi darurat. Perkecualian tersebut dikenal dengan Emergency Protection, ialah suatu tindakan pengamanan kepada industri domestik disaat mengalamikeadaan dimana lonjakan impor atau adanya ancaman yang bisa nantinya memunculkan kerugian yang berat atau serius.

Umumnya, upaya itu bertentangan dengan isi dari Pasal 2 dan Pasal 11 GATT 1994. Namun masih bisa dibenarkan dengan menggunakan dasar padaPasal 19 GATT 1994, asalkan memenuhi segala syarat yang dikehendaki oleh isi dalam pasal tersebut, dimana yang menjadi tujuan dari upaya pengamanan perdagangan ialah guna menyediakan kebebasan bagi industri domestik serta guna menyediakan waktu bagi berbagai industri domestik untuk bisa menyesuaikan diri terhadap berbagai kondisi pasar baru (Peter Van Den Bossche, et al, 2010, 69).

Sesuai dengan yang diatur dalam Pasal XIX GATT 1994, upaya pengamanan perdagangan hanya bisa dilaksanakan jika tiga syarat berikut telah dipenuhi, yaitu:

a. Lonjakan Impor

Salah satu syarat mengenai lonjakan impor harus terjadi dalam waktu dekat, tiba-tiba, atau di dalam jangka waktu yang tidak lama, signifikan dan tajam. Apalagi lonjakan impor tersebut mesti tidak bisa diprediksi pada sebelumnya. Melalui langkah ini maka bisa ambil kesimpulan apakah 
suatu keadaan dan situasi tertentu itunya tanya merupakan suatu keadaan yang darurat. Apabila lonjakan impor telah berlangsung lama atau perisitiwa tersebut hanya terjadi selama periode yang beberapa saat kemudian peristiwa tersebut bisa dilakukan prediksi pada waktu sebelumnya, maka tidak bisa dinyatakan yaitu terdapat kadaan darurat sesuai dengan yang telah ditentukan sebagai syarat di dalam Pasal XIXs GATT 1994.

b. Kerugian Serius

Kerugian yang bisa dikatakan serius terjadi jika terdapat kerugian secara menyeluruh dan signifikan diderita oleh industri domestik. Kerugian serius adalah syarat yang lebih susah dipenuhi dibandingkan dengan syarat kerugian material lain yang diberlakukan kepada pengenaan upaya anti dumping ataupun tindakan retaliasi. Ini bukan hal yang mengagetkan sebab upaya pengamanan perdagangan diberlakukan kepada perdagangan yang bersifat fair, sedangkan tindakan retaliasi atau anti-dumping diberlakukan kepada perdagangan yang bersifat tidak fair. Guna memastikan apakah ada ancaman kerugian serius atau tidaknya, jadi terdapat halhal yang mesti mendapat perhatian, yaitu:

1) Nilai ataupun jumlah dari lonjakan impor oleh barang yang dijadikan masalah tersebut dilihat dengan cara relatif dan absolut.

2) Pangsa dari pasar domestik yang dikuasai oleh lonjakan impor itu.

3) Perubahan dari tindakan kemampuan untuk berproduksi, kapasitas yang digunakan, produksi, penjualan, keuntungan serta kerugian kemudian tenaga kerja.

c. Hubungan dari Kausal Syarat ketiga yang merupakan persyaratan subtantif terakhir pada suatu upaya peng- amanan perdagangan yaitu syarat adanya hubungan kausal. Terdapat dua (2) pengecekan yang harus dilaksanakan guna menunjukkan bukti bahwa terdapat hubungan kausal itu, yakni:

1) Membuktikan bahwa terdapat hubungan kausal di antara lonjakan impor dengan kerugian serius ataupun ancaman terhadapnya.

2) Mengidentifikasikan kerugian yang dimunculkan dari sebab faktor-faktor lain diluar faktor lonjakan impor serta tidak menimbulkan kerugian pada impor yang dijadikan masalah.

\section{Penerapan Aturan Perkecualian}

Penerapan Aturan Perkecualian Terhadap Larangan Restriksi Kuantitatif yang Mencerminkan Keadilan dalam Penanaman Modal Khususnya Bagi Indonesia

Keadilan sebagai fairness telah dikemukakan sebelumnya dalam tulisan ini, dimana penggagas utama dari keadilan sebagai fairness adalah John Rawls. Prinsip dari keadilan sebagai fairness adalah pada keadilan sosial yang dengan maksud memberikan kemudahan dalam membagi antara kewajiban maupun hak, sehingga dapat menjadi penentu dalam membagi keuntungan maupun pembebanan dari suatu bentuk kerja sama secara layak.

Keadilan yang hidup dalam hukum bagi John Rawls harus dapat memberikan keuntungan terutama untuk masyarakat yang dapat digolongkan paling kurang beruntung. Sehingga dengan berdasarkan pada prinsip yang dianutnya yaitu keadilan dapat memberikan keuntungan yang sama rata bagi tiap masyarakat, namun apabila terdapat perbedaan kondisi maupun situasi, maka keuntungan itu perlu diutamakan bagi masyarakat yang paling kurang beruntung. Dengan begitu dapat menciptakan suatu keseimbangan sosial ekonomi yang tercermin dalam suatu masyarakat. 


\section{Perkecualian terhadap Prinsip Larangan Pembatasan Kuota Impor Terkait Penanaman Modal di Indonesia}

Resa Raytiaputri

Berkaitan dengan gagasan teori keadilan sebagai fairness oleh John Rawls tersebut yang mengatakan adanya perbedaan kondisi atau situasi dalam pembahasan ini adalah mengenai penanaman modal. Dimana subyek dari penanaman modal adalah penanam modal dan penerima modal. Karena penanaman modal berkaitan dengan prinsip yang diatur oleh hukum perdagangan internasional, sudah pasti ruang lingkup pembahasannya pun tidak jauh dari hukum internasional. Sedangkan hukum internasional mengatur hak-hak dan kewajiban negara, dimana negara sebagai subyek dari penanaman modal asing. Dan untuk memperoleh gambaran jelas mengenai suatu negara, maka diperlukan unsur-unsur konstitutif bagi pembentukan suatu negara. Unsur-unsur konstitutif itu meliputi penduduk yang tetap, wilayah tertentu, pemerintah dan kedaulatan (Boer Mauna, 2010, 17-24).

Unsur-unsur dalam masing-masing negara tersebut dapat berbeda-beda, maka kondisi tiap negara pun juga berbeda. Pada dasarnya unsurunsur tersebut yang berpengaruh dalam keberlangsungan hidup maupun kemampuan negara dalam melaksanakan kegiatan kenegaraannya, tak terkecuali kegiatan dalam bidang perekonomian. Hal tersebut yang pada akhirnya menciptakan taraf keunggulan komparatif berbeda pada setiap negara.

Berdasar pada teori siklus produk atau The Product Cycle Theory, yang mengurutkan setiap teknologi atau produk berevolusi melalui tiga fase, yaitu (Hendrik Budi Untung, 2013, 27): mulai dari fase pertama, dimana negara-negara maju mendominasi perdagangan, selama fase awal ini, perusahaan di negara maju menikmati suatu posisi monopoli, terutama karena teknologinya. Kemudian pada fase kedua, yaitu proses manufacturing terus berkembang dan tempat produksi cenderung berkembang di negara-negara maju lainnya. Yang terakhir fase ketiga, adanya standardisasi proses manufacturing memungkinkan peralihan lokasi- lokasi produksi ke negara-negara yang sedang berkembang. Sejalan dengan teori yang diusung oleh Adam Smith mengenai teori klasik perkembangan ekonomi, dimana perekonomian akan mengalami perkembangan melalui pasar perdagangan bebas dan kompetisi bagi para pihak untuk menguntungkan dirinya masing-masing.

Hal di atas yang menjadi panutan dalam dunia ekonomi sehingga diaplikasikan dalam kegiatan perdagangan yang terbuka seluas-luasnya dan sebebas-bebasnya dalam ekonomi internasional hingga saat ini. Keberadaan prinsip nondiskriminasi mengakibatkan perusahaan dari negara berkembang nantinya bisa menghadapi kesulitan ketika bersaing dengan negara maju yang diketahui memiliki tingkat teknologi yang jauh lebih maju. Namun, sejumlah negara berkembang cenderung mengalami kerugian yang disebabkan kegiatan ekonomi internasional, khususnya impor produk sebagai modal, yang hanya memiliki tujuan awal mengumpulkan keuntungan saja.

Melonjak derasnya komoditas produksi dari asing di dalam pasar lokal nantinya dapat mengakibatkan pelaku ekonomi dalam negeri terpukul dengan adanya penurunan harga dan bahan baku industri yang nantinya bisa membuat permintaan terhadap produk dalam negeri mengalami penurunan bahkan kematian di pasar dalam negeri.

Kesepakatan WTO dengan berlakunya perjanjian GATT yang salah satunya adalah tindakan perkecualian terhadap larangan rekstriksi kuantitatif atau safeguards. Tindakan tersebut diberlakukan dengan maksud untuk menghindari keadaan, dimana anggota WTO menghadapi suatu dilema antara membiarkan pasar dalam negeri mereka yang sangat terganggu oleh barang impor atau menarik diri dari kesepakatan.

Apabila pilihan kedua yang dipilih oleh banyak negara, maka hal itu akan menimbulkan ketidak efektifan proses liberalisasi. Sehingga prinsip perkecualian terhadap larangan restriksi kuantitatif atau safeguards tersebut telah menjadi jalan 
tengah yang terbaik dan mencerminkan teori keadilan dengan gagasan fairness, sebagai jalan aman agar terwujud saling menguntungkan tanpa memberatkan ataupun mengakibatkan kerugian bagi negara berkembang yang berada pada posisi lemah.

Indonesia sebagai salah satu negara berkembang yang ikut terlibat dalam aktifitas perekonomian dunia, tidak lepas dari berbagai permasalahan. Misalnya pada salah satu kasus impor gandum dan tepung terigu yang meresahkan petani lokal di Indonesia, sehingga pemerintah Indonesia mengambil sebuah tindakan untuk membatasi kuota impor. Kondisi itu berlangsung terus menerus hingga saat ini dan menciptakan ketergantungan lewat impor besar-besaran karena tidak dibarengi dengan pemberdayaan potensi lokal.

Atas kondisi itu, Kementerian Perdagangan telah membatasi izin impor tepung terigu dengan menerapkan sistem kuota. Hal tersebut dilakukan dengan tujuan agar industri tepung terigu lokal tidak terganggu dengan serbuan produk impor tepung terigu. Pada tanggal 28 April 2014, pemerintah Indonesia mengeluarkan Peraturan Menteri Perdagangan Republik Indonesia Nomor 23/MDAG/PER/4/2014 tentang Ketentuan pengenaan kuota dalam rangka tindakan pengamanan perdagangan terhadap impor tepung terigu.

Peraturan tersebut mengacu pada ketentuan pasal 70 Peraturan Pemerintah Nomor 34 tahun 2011 tentang Tindakan Anti Dumping, tindakan imbalan dan tindakan pengamanan perdagangan, terhadap barang impor yang mengalami lonjakan jumlah impor, dapat dikenakan bea masuk tindakan pengamanan dan/atau kuota. Kebijakan tersebut menimbang hasil penyelidikan Komite Pengamanan Perdagangan Indonesia (KPPI) yang membuktikan adanya kerugian serius yang dialami oleh industri dalam negeri sebagai akibat lonjakan impor gandum dan merekomendasikan untuk dikenakan tindakan pengamanan perdagangan berupa bea masuk tindakan pengamananan atau kuota.

\section{Perwujudan Aturan Perkecualian Dalam} Pengaturan Penanaman Modal di Indonesia

Dengan ditetapkannya ketentuan penanaman modal melalui Undang-undang tentang Penanaman Modal Nomor 25 tahun 2007 sebagai pengganti Undang-undang Noomo 1 tahun 1967 tentang PMA dan Undang-undang Nomor 6 tahun 1967 tentang PMDN telah mengakhiri dualisme pengaturan tentang penanaman modal apakah itu penanaman modal asing, maupun penanaman modal dalam negeri. Selain itu, kehadiran Undangundang yang baru ini sekaligus mempertegas dan memperjelas kebijakan pengaturan penanaman modal di Indonesia, yang kemudian pada rumusan masalah kedua dalam tulisan ini akan dianalisa oleh penulis terutama kaitannya dengan perwujudan perkecualian terhadap prinsip larangan restriksi kuantitatif.

1. Pengaturan Penanaman Modal di Indonesia berdasar Undang-undang Nomor 25 Tahun 2007 Tentang Penanaman Modal

Undang-undang Nomor 25 Tahun 2007 tentang Penanaman Modal telah dijadikan pedoman dalam penyelenggaraan penanaman modal di Indonesia. Melalui beberapa pertimbangan, akhirnya pemerintah telah mengeluarkan berbagai paket kebijakan, antara lain dengan mengesahkan dan memberlakukan Undangundang Nomor 25 Tahun 2007 tentang Penanaman Modal yang merupakan bukti adanya jaminan kepastian hukum bagi investor untuk berinvestasi di Indonesia.

Undang-undang Nomor 25 Tahun 2007 Pasal 26 telah mengatur secara tegas tentang pelayanan terpadu satu pintu dengan tujuan membentuk penanam modal/investor dalam memperoleh kemudahan pelayanan, fasilitas fiskal, dan informasi mengenai penanaman modal/ investasi yang dilakukan oleh lembaga atau instansi yang berwenang di bidang penanaman modal yang mendapat pendelegasian atau 
pelimpahan wewenang dari lembaga atau instansi yang memiliki kewenangan perizinan dan non perizinan di tingkat pusat atau lembaga atau instansi yang berwenang mengeluarkan perizinan dan non perizinan di provinsi atau kabupaten/kota.

Tujuan penyelenggaraan penanaman modal hanya dapat tercapai, apabila faktor penunjang yang menghambat iklim penanaman modal dapat diatasi, antara lain melalui perbankan, koordinasi antar instansi pemerintah pusat dan daerah, penciptaan birokrasi yang efisien, kepastian hukum di bidang penanaman modal, biaya ekonomi yang berdaya saing tinggi, serta iklim usaha yang kondusif di bidang ketenagakerjaan dan kemanan berusaha.

Dengan perbaikan berbagai faktor penunjang tersebut, diharapkan realisasi penanaman modal akan membaik secara signifikan dengan berlandaskan pada asas-asas, yaitu kepastian hukum, keterbukaan, akuntabilitas, perlakuan yang sama dan tidak membedakan asal negara, kebersamaan, efisiensi berkeadilan, berkelanjutan, berwawasan lingkungan, kemandirian, dan keseimbangan kemajuan dan kesatuan ekonomi nasional (Hendrik Budi Untung, 2013, 42-44).

Disamping asas-asas tersebut, Undang-undang Penanaman Modal di Indonesia dibangun diatas prinsip-prinsip penanaman modal, yakni perlakuan sama dalam bidang usaha, penerapan syarat penanaman modal, perlakuan khusus terhadap negara-negara tertentu, serta fasilitas penanaman modal.

\section{Aturan Hukum di Indonesia yang Mencermin- kan Perwujudan Pengaturan Perkecualian Terhadap Prinsip Larangan Restriksi Kuantitatif}

Indonesia seperti diketahui oleh berbagai kalangan memiliki kondisi internal yang menjadikannya memiliki keunggulan komparatif (compara- tive advantage). Keunggulan komparatif itu antara lain adanya stabilitas ekonomi dan politik, kemudahan dan relatif murahnya memperoleh faktor produksi yang berupa tenaga kerja dan sumber kekayaan alam yang melimpah. Namun keunggulan komparatif tersebut masih harus didukung oleh keunggulan kompetitif yang pada umumnya dimiliki oleh investor asing.

Pengaturan penanaman modal di Indonesia sendiri sudah dibentuk dalam Undang-undang yaitu Undang-undang Nomor 25 Tahun 2007 tentang Penanaman Modal yang memiliki beberapa asas-asas untuk menerapkan kepastian hukum dan mencerminkan perlindungan kepentingan nasional paling dekat kaitannya dengan prinsip safeguards yang tertera pada Pasal 3 ayat (1) dan dijelaskan sebelumnya.

Namun aturan secara eksplisit mengenai Pengaturan Perkecualian Terhadap Prinsip Larangan Restriksi Kuantitatif masih belum diatur. Aturan tersebut hanya tertera secara tidak langsug dalam persyaratan penanaman modal pada Undang-undang Nomor 25 Tahun 2007 tentang Penanam Modal di Indonesia. Berdasarkan prinsipprinsip dasar tersebut, berikut diuraikan analisis tentang persyaratan penanaman modal di Indonesia.

Undang-undang Nomor 25 Tahun 2007 tidak membuka seluruh bidang usaha bagi kegiatan penanaman modal asing. Pasal 12 Undang-undang ayat (2) tersebut menetapkan bahwa bidang usaha yang terkait langsung dengan keamanan negara. Ayat (3) selanjutnya menetapkan bidang usaha yang tertutup bagi penanaman modal asing berdasarkan alasan kesehatan, moral, kebudayaan, lingkungan hidup, pertahanan dan keamanan nasional, serta kepentingan nasional lainnya.

Lebih lanjut dalam Pasal 12 ayat (5) ditegaskan bahwa pemerintah dapat menetapkan bidang usaha yang terbuka dengan persyaratan berdasarkan kriteria kepentingan nasional, yaitu perlindungan sumber daya alam, perlindungan, pengem- 
bangan usaha mikro, kecil, menengah, dan koperasi, pengawasan produksi dan distribusi, peningkatan kapasitas teknologi, partisipasi modal dalam negeri, serta kerja sama dengan badan usaha yang ditunjuk pemerintah.

Pasal 10 Undang-undang Nomor 25 Tahun 2007 mewajibkan perusahaan penanaman modal dalam memenuhi kebutuhan tenaga kerja untuk mengutamakan tenaga kerja Warga Negara Indonesia. Perusahaan penanaman modal berhak menggunakan tenaga ahli warga negara asing untuk jabatan dan keahlian tertentu sesuai dengan ketentuan peraturan perundang-undangan. Perusahaan penanaman modal yang mempekerjakan tenaga kerja asing diwajibkan menyelenggarakan pelatihan dan melakukan alih teknologi kepada tenaga kerja warga negara Indonesia sesuai dengan ketentuan peraturan perundang-undangan.

UU PM mengatur tentang Fasilitas Penanaman Modal pada Bab X mulai dari Pasal 18 sampai dengan Pasal 24. Secara umum tidak ada ketentuan perdagangan internasional yang melarang pemberlakuan insentif investasi berupa fasilitas penanaman modal. Masalah bisa muncul jika pemberian insentif investasi dikaitkan dengan performance requirement yang bertentangan dengan Agreement onTRIMs.

Pasal 12 ayat (4) UU PM memberikan hak kepada pemerintah untuk menetapkan syarat-syarat penanaman modal pada bidang usaha yang terbuka bagi penanaman modal. Selanjutnya pada ayat (5) ditetapkan kriteria kepentingan nasional yang harus diperhatikan dalam menetapkan persyaratan penanaman modal, yakni perlindungan sumber daya alam, perlindungan, pengembangan usaha mikro, kecil, menengah, dan koperasi, pengawasan produksi dan distribusi, peningkatan kapasitas teknologi, partisipasi modal dalam negeri, serta kerja sama dengan badan usaha yang ditunjuk Pemerintah.

Di samping itu ketentuan tentang tindakan safeguards di Indonesia diatur dalam Undang- undang Nomor 7 Tahun 1994 tentang Pengesahan Agreement Establishing The World Trade Organization. Peraturan lebih lanjut ditetapkan dalam bentuk Keputusan Presiden Nomor 84 Tahun 2002 tentang Tindakan Pengamanan Industri Dalam Negeri dari Akibat Lonjakan Impor.

Industri dalam negeri yang mengalami kerugian serius atau ancaman kerugian serius yang disebabkan oleh lonjakan impor barang serupa atau secara langsung tersaingi dapat mengajukan permohonan penyelidikan tindakan safeguards kepada Komite Pengamanan Perdagangan Indonesia (KPPI). Pihak-pihak yang dapat mengajukan permohonan tersebut adalah produsen, asosiasi produsen, organisasi pekerja, importir, asosiasi importir, industri pemakai, eksportir, asosiasi eksportir, pemerintah dan perorangan atau badan hukum yang terkait.

Tanggal 23 April 2014, Presiden RI telah menetapkan Peraturan Presiden Nomor 39 Tahun 2014 tentang Daftar Bidang Usaha yang Tertutup dan Bidang Usaha yang Terbuka Dengan Persyaratan di Bidang Penanaman Modal. Selanjutnya Perpres tersebut diundangkan pada tanggal 24 April 2014 melalui Lembaran Negara Republik Indonesia Tahun 2014 Nomor 93. Dimana undang-undang ini dibentuk dalam rangka pelaksanaan dari Pasal 12 dan 13 Undang-undang Penanaman Modal, yang di dalam aturan ini membagi 3 (tiga) kelompok bidang usaha yaitu: bidang usaha yang tertutup, merupakan bidang usaha tertentu yang dilarang diusahakan sebagai kegiatan penanaman modal; bidang usaha yang terbuka dengan persyaratan, adalah bidang usaha tertentu yang dapat diusahakan sebagai kegiatan penanaman modal dengan syarat tertentu, yaitu bidang usaha yang dicadangkan untuk Usaha Mikro, Kecil, Menengah dan Koperasi, bidang usaha yang dipersyaratkan dengan kemitraan, bidang usaha yang dipersyaratkan kepemilikan modalnya, bidang usaha yang dipersyaratkan dengan lokasi tertentu, dan bidang usaha yang dipersyaratkan dengan per- 
izinan khusus; bidang usaha yang terbuka tanpa persyaratan.

Kemudian Undang-undang Nomor 40 Tahun 2007 tentang Perseroan Terbatas, selanjutnya disebut Undang-Undang Perseroan Terbatas. Undang-undang Perseroan Terbatas memiliki keterkaitan erat dengan penanaman modal asing yang diatur oleh Undang-undang Penanaman Modal, dalam hal bentuk usaha yang dibentuk untuk melakukan penanaman modal. Hal ini dapat dilihat pada Pasal 5 ayat (2) Undang-Undang Penanaman Modal, dimana diatur bahwa penanaman modal asing wajib berbentuk perseroan terbatas berdasarkan hukum lndonesia dan berkedudukan di dalam wilayah Negara Republik Indonesia, kecuali ditentukan lain oleh undang-undang.

Undang-undang Nomor 3 Tahun 2014 tentang Perindustrian, selanjutnya disebut Undangundang Perindustrian. Undang-undang Perindustrian memuat ketentuan bahwa pembatasan kepemilikan modal asing diatur dalam pengelolaan Industri Strategis. Adapun yang dimaksud dengan Industri Strategis adalah Industri yang penting bagi negara dan yang menguasai hajat hidup orang banyak, meningkatkan atau menghasilkan nilai sumber daya alam strategis, atau mempunyai kaitan dengan kepentingan pertahanan serta keamanan negara dalam rangka pemenuhan tugas pemerintah negara (Pasal 1 angka 4 dan Pasal 84 Undang-undang Perindustrian).

Penguasaan Industri Strategis oleh negara sebagaimana dimaksud dilakukan melalui pengaturan kepemilikan; penetapan kebijakan; pengaturan perizinan; pengaturan produksi, distribusi, dan harga; dan pengawasan. Pengaturan kepemilikan Industri Strategis sebagaimana dimaksud dilakukan melalui penyertaan modal seluruhnya oleh Pemerintah; pembentukan usaha patungan antara Pemerintah dan swasta; atau pembatasan kepemilikan oleh penanam modal asing (Pasal 84 Undangundang Perindustrian).
Dengan demikian, terlihat aturan hukum di Indonesia yang mencerminkan dari perwujudan perkecualian terhadap larangan restriksi kuantitatif atau dengan kata lain memperbolehkan melaksanakan pembatasan khususnya kuota.

\section{Penutup}

Keberadaaan aturan perkecualian terhadap prinsip larangan restriksi kuantitatif didasarkan untuk menciptakan suatu keadaan yang seimbang ketika ada negara anggota WTO yang mengalami situasi lonjakan impor yang mengancam negara tersebut sehingga mengalami kerugian. Hal tersebut memiliki sifat yang menentang isi aturan dari Pasal XI GATT yang aturannya melarang pelaksanaan restriksi kuantitatif, namun hal ini dibenarkan jika mendasar pada Pasal XIX GATT bila memenuhi persyaratan terdapat kondisi adanya hubungan dari lonjakan impor, kerugian serius kemudian hubungan kausal diantaranya.

Berdasar pada kondisi Indonesia saat ini, penanaman modal asing sangat diperlukan sebab bisa memberi bantuan dalam peningkatan pendapatan negara, peningkatan dalam perekonomian masyarakat, kemudian pendapatan asli daerah, sehingga teori klasik bisa diberlakukan dalam rangka guna mengundang investor asing ke Indonesia. Namun kegiatan impor juga dapat menjadi ancaman bagi pasar nasional Indonesia sendiri jika tidak mendapat perhatian lebih dari pemerintah yang berperan sebagai pembuat kebijakan terkait dengan urusan perdagangan internasioal dan penanaman modal.

Keberadaan aturan perkecualian ini dirasa masih belum sepenuhnya mencerminkan keadilan khususnya bagi negara berkembang seperti Indonesia, masih ada cela bagi negara maju atau perusahaan multinasional yang memiliki keunggulan modal untuk diutamakan kepentingannya, namun semua kembali pada usaha maupun kekuatan suatu 
negara untuk dapat mempertahankan kedaulatan negaranya sendiri. Hal penting yang dapat diambil dari serangkaian perisitiwa diplomasi internasional khususnya di Indonesia sendiri yaitu bahwa setiap langkah diplomasi internasional ialah fungsi dari kebijakan domestik suatu negara. Sukar dapat diharapkan hasil diplomasi perdagangan internasional yang baik jika masih adanya masalah terkait kebijakan ekonomi di dalam negeri. Berkebalikan dengan itu, jika kebijakan di dalam suatu negera sangat solid, terstruktur, terkoordinasi dengan tujuan yang jelas, maka para diplomat dapat relatif mudah dalam menuangkannya menjadi beberapa langkah strategis.

Perwujudan pengaturan perkecualian terhadap larangan restriksi kuantitatif dalam pengaturan penanaman modal di Indonesia tertuang dalam bentuk pembatasan bidang usaha seperti yang dikandung Undang-undang Nomor 25 Tahun 2007 tentang Penanaman Modal, kemudian dilaksanakan dengan dasar hukum Peraturan Presiden Nomor 39 Tahun 2014 tentang Daftar Bidang Usaha yang Tertutup dan Bidang Usaha yang Terbuka Dengan Persyaratan di Bidang Penanaman Modal. Kemudian mengingat permasalahan seperti impor tepung terigu dan hortikultura, sehingga Indonesia membuat kebijakan berbentuk Peraturan Menteri Perdagangan Republik Indonesia Nomor 23/M-DAG/PER/4/2014 tentang Ketentuan pengenaan kuota dalam rangka tindakan pengamanan perdagangan terhadap impor tepung terigu, sertaUndang-undang 13/2010 tentang Hortikultura dan Undang-undang 18/2009 tentang Peternakan dan Kesehatan Hewan. Lebih khusus lagi, Peraturan Menteri Pertanian (Permentan) Nomor 50/ 2011 tentang Rekomendasi Persetujuan Impor Karkas, Daging, Bagian Lain dan Produk Olahan dan Pementan 60/2012 tentang Rencana Impor Produk Hortikultura (RIPH), Peraturan Menteri Perdagangan (Permendag) Nomor 24 Tahun 2012 (yang sebenarnya telah diperbarui menjadi Permendag 60/2012) tentang Ketentuan Impor Produk Hewan (KIPH) dan berbagai aturan lainnya seperti Undang-undang Perseroan Terbatas, Undang-Undang Perindustrian, dan lain sebagainya.

Penanaman modal, tidak selalu berdampak positif bagi perekonomian suatu negara, tetapi sebaliknya, dapat menjadi katalis bagi kemunduran ekonomi, khususnya pada sektor riil. Di Indonesia, penanaman modal asing tidak jarang menerabas akses bagi pengusaha kecil menengah untuk mengembangkan usahanya. Kalah dalam kecanggihan teknologi serta kualitas produk menyebabkan mereka menjadi inferior dan kurang memiliki daya saing, baik lokal maupun internasional. Alihalih memberi lapangan lapangan kerja baru bagi pribumi, penanaman modal asing justru menjelma menjadi penindas dan bahkan menghilangkan lapangan kerja mereka selama ini.

\section{Daftar Pustaka}

\section{Buku}

Bossche, Peter Van Den, dkk, 2010, Pengantar Hukum WTO (Word Trade Organisation), cetakan pertama, Yayasan Obor Indonesia, Jakarta.

Mauna, Boer, 2010, Hukum Internasional - Pengertian, Peranan dan Fungsi dalam Era Dinamika Global, Alumni, Bandung.

Pangestu, Mari, 1996, Perjanjian Internasional Mengenai Investasi GATT 1994/WTO dan APEC, PertaminaKomite Nasional Indonesia-World Energy Council, Jakarta.

Rakhmawati, N. Rosyidah, 2004, Hukum Penanaman Modal di Indonesia, Bayumedia Publishing, Malang.

Rakhmawati, N. Rosyidah, 2006, Hukum Ekonomi Internasional dalam Era Global, Bayumedia Publishing, Malang.

Untung, Hendrik Budi, 2013, Hukum Investasi, Sinar Grafika, Jakarta. 


\section{Perkecualian terhadap Prinsip Larangan Pembatasan Kuota Impor Terkait Penanaman Modal di Indonesia}

Resa Raytiaputri

\section{Artikel}

Arifin, Bustanul, 4 Februari 2013, Diplomasi Hortikultura Dimulai dari Dalam Negeri - Analisis Ekonomi, Kompas.

United Nations, 1991, The Impact of Trade Related Investment Measures; Theory, Evidency and Policy Implication, United Nations, New York.

\section{Peraturan Perundang-undangan}

General Agreement on Tariff and Trade (GATT) 1994.

Peraturan Presiden Nomor: 39 Tahun 2014 tentang Daftar Bidang Usaha yang Tertutup dan Bidang Usaha yang Terbuka Dengan Persyaratan di Bidang Penanaman Modal.
Undang-Undang Nomor: 25 Tahun 2007 tentang Penanaman Modal.

Undang-Undang Nomor: 40 Tahun 2007 tentang Perseroan Terbatas.

Undang-Undang Nomor: 3 Tahun 2014 tentang Perindustrian

Undang-Undang Nomor: 7 Tahun 1994 tentang Pengesahan Agreement Establishing The World Trade Organization.

Surat Keputusan Menteri Perindustrian dan Perdagangan Nomor: 23/MPP/Kep/1/1998 mengenai Pelaksanaan Dari Lembaga-Lembaga Usaha Perdagangan. 